\title{
ABCF2 wt Allele
}

National Cancer Institute

\section{Source}

National Cancer Institute. ABCF2 wt Allele. NCI Thesaurus. Code C113328.

Human ABCF2 wild-type allele is located in the vicinity of $7 q 36$ and is approximately $19 \mathrm{~kb}$ in length. This allele, which encodes AT P-binding cassette sub-family F member 2 protein, is involved in ATP hydrolysis. 